Gut, 1968, 9, 91-95

\title{
Effect of intravenous iron therapy on gastric acid secretion in iron-deficiency anaemia
}

\author{
H. G. DESAI, B. C. MEHTA, A. V. BORKAR, AND K. N. JEEJEEBHOY \\ From the Medical Division, Radiation Medicine Centre, Bhabha Atomic Research Centre, \\ Tata Memorial Hospital, Parel, Bombay, India
}

In patients with iron-deficiency anaemia, acid secretion was found to be reduced and was associated with chronic gastritis (Davidson and Markson, 1955; Joske, Finckh, and Wood, 1955; Badenoch, Evans, and Richards, 1957; Lees and Rosenthal, 1958; Floch and Meroney, 1962; Bock, Richards, and Witts, 1963; Dagg, Goldberg, Anderson, Beck, and Gray, 1964; Ikkala and Siurala, 1964; Cowan, Joseph, and Satija, 1966). However, in some patients with iron-deficiency anaemia, discrepancies were observed between the gastric mucosal lesion and acid output (Davidson and Markson, 1955; Glass, Speer, Nieburgs, Ishimori, Jones, Baker, Schwartz, and Smith, 1960; Adams, Glen, Kennedy, Mackenzie, Morrow, Anderson, Gray, and Middleton, 1964), suggesting that some other factors, such as anaemia and/or deficiency of an iron-dependent enzyme system, might also contribute to reduction in acid output (Floch and Meroney, 1962; Shearman, Delamore, and Gardner, 1966).

After correction of the anaemia with oral or intramuscular iron, an increase in acid output was noted by some (Leonard, 1954; Badenoch et al., 1957; Jacobs, Lawrie, Entwhistle, and Campbell; 1966) while others reported neither histological nor functional improvement (Davidson and Markson, 1955; Floch and Meroney, 1962; Vaish, Sampathkumar, Jacob, and Baker, 1965); if anything, the changes worsened over a period of one year (Lees and Rosenthal, 1958). Jacobs et al. (1966) observed that the improvement in acid output, after correction of anaemia, occurs in patients under 30 years of age but not in elderly subjects. In a patient with irondeficiency anaemia, acid output was also studied within a week, before and after intravenous iron administration, to observe whether any iron-containing enzyme system was deficient and was responsible for reduction in acid output; the results were inconclusive (Shearman et al., 1966).

The aim of this study was to observe the early effect of intravenous iron therapy on acid output (before the correction of anaemia) in patients with severe iron-deficiency anaemia.

\section{MATERIAL AND METHODS}

PATIENTS Thirty-six patients with untreated severe irondeficiency anaemia (haemoglobin $<7 \mathrm{~g} . / 100 \mathrm{ml}$.) of varied aetiology were selected for study. The diagnosis of iron-deficiency anaemia was based on a complete blood count, a stained blood film, serum iron, iron-binding capacity, and bone marrow examination.

METHODS Standard haematological techniques were used (Dacie and Lewis, 1963). Serum iron and iron-binding capacity were estimated by the method of Ramsay (1957).

Histamine infusion test In a fasting subject, a 14-18 Fr Levine tube was placed along the greater curvature with the tip in the most dependent part of the stomach with the aid of fluoroscopy. The subjects were instructed to lie in the left lateral position and to expectorate saliva during the period of collection. The gastric secretion was collected by continuous hand suction. Acid output was measured by a modification of the histamine infusion test described by Lawrie, Smith, and Forrest (1964). To ensure a maximal stimulus in underweight subjects, a fixed dose of $2.0 \mathrm{mg}$. of histamine acid phosphate per hour was given intravenously to all subjects weighing less than $50 \mathrm{~kg}$., and a standard dose of $0.04 \mathrm{mg} . / \mathrm{kg}$. body weight $/ \mathrm{hr}$ was administered to subjects weighing more than $50 \mathrm{~kg}$. The volume, the maximal histamine response (MHR), and the minimum $p \mathrm{H}$ of gastric secretion were recorded. To judge the reproducibility of the results, the histamine infusion test was repeated in 12 control subjects, and was repeated in 36 patients with irondeficiency anaemia within 48 to 72 hours after the administration of intravenous iron and in four or five days following the first test. Iron-dextran (Imferon) was given as a single dose in $5 \%$ glucose solution by a slow intravenous drip lasting over four to six hours: the total dose varied from 1.5 to $2.5 \mathrm{~g}$. elemental iron.

Gastric biopsy In 10 patients, gastric biopsy was obtained from the body of the stomach with a Crosby capsule (Crosby and Kugler, 1957). The histological appearances were classified according to the criteria of Williams, Edwards, Lewis, and Coghill (1957).

\section{RESULTS}

The haematological data and the aetiology of irondeficiency anaemia are given in Table I. In 27 
TABLE I

\begin{tabular}{|c|c|c|c|c|c|c|c|c|}
\hline \multirow{3}{*}{ Sex } & \multicolumn{8}{|c|}{ HAEMATOLOGICAL DATA AND AETIOLOGICAL FACTORS IN IRON-DEFICIENCY ANAEMLA } \\
\hline & \multirow[t]{2}{*}{$\operatorname{Age}(y r)$} & \multirow[t]{2}{*}{$H b(g . / 100 \mathrm{ml})}$. & \multirow{2}{*}{$\begin{array}{l}\text { Serum iron } \\
(\mu \mathrm{g} . / 100 \mathrm{ml} .)\end{array}$} & \multirow{2}{*}{$\begin{array}{l}\text { T.I.B.C. } \\
(\mu \mathrm{g} . / 100 \mathrm{ml} .)\end{array}$} & \multicolumn{4}{|c|}{ Cause of Iron-deficiency Anaemia } \\
\hline & & & & & Ankylostomiasis & Piles & $\begin{array}{l}\text { Multiple } \\
\text { Pregnancies }\end{array}$ & Idiopathic \\
\hline $\begin{array}{l}\text { Male } \\
(21) \\
\text { Female } \\
(15)\end{array}$ & $\begin{array}{l}34 \cdot 3 \\
(16 \cdot 60) \\
28 \cdot 5 \\
(16-50)\end{array}$ & $\begin{array}{l}3 \cdot 7 \\
(1 \cdot 5-6 \cdot 5) \\
4 \cdot 4 \\
(2 \cdot 0-7 \cdot 0)\end{array}$ & $\begin{array}{l}28 \cdot 8 \\
(12-100)^{1} \\
32 \cdot 6 \\
(10-70)\end{array}$ & $\begin{array}{l}470 \cdot 5 \\
(155-934) \\
474 \cdot 6 \\
(267-666)\end{array}$ & $\begin{array}{l}13 \\
4\end{array}$ & 2 & $\mathbf{0}$ & 6 \\
\hline
\end{tabular}

${ }^{1}$ Only one patient had serum iron of higher than $70 \mu \mathrm{g} . / 100 \mathrm{ml}$. T.I.B.C. $=$ total iron binding capacity.

patients the iron-deficiency anaemia was secondary to blood loss while in nine patients the cause of iron-deficiency anaemia was not obvious ('idiopathic').

REPRODUCIBILITY OF THE HISTAMINE INFUSION TEST The mean and standard deviation (SD) of the differences between the two tests in the same control subjects were $1.1 \pm 0.56 \mathrm{~m}$-equiv/ $\mathrm{hr}(\mathrm{SE}=0.23)$. The differences were statistically not significant $(P=0.4)$.

VOLUME OF GASTRIC SECRETION Before and after iron therapy, the average volume of gastric secretion was the same, about $160 \mathrm{ml}$, which was much lower than the average volume $(250 \mathrm{ml}$.) secreted by control subjects. The values for the maximum histamine response in 36 patients with iron-deficiency anaemia, before and after intravenous iron therapy, are

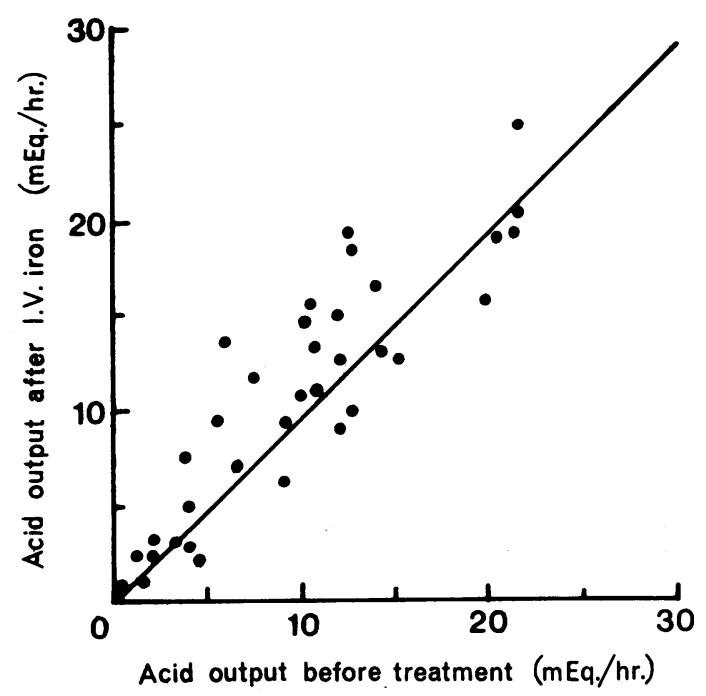

FIG. 1 The maximal response to the histamine infusion test in 36 patients with iron-deficiency anaemia before and after intravenous iron therapy. shown in Figure 1. Before and after intravenous iron therapy, the values were $10.9 \pm 7.94$ m-equiv/ $\mathrm{hr}$ and $11.65 \pm 7.42 \mathrm{~m}$-equiv/hr respectively. The differences were not significant $(P=0 \cdot 3)$. The mean and SD of the differences between the two tests in the same patient were $0.74 \pm 3.07 \mathrm{~m}$-equiv/hr. The differences were not significant $(P>0.05)$.

$p$ H OF GASTRIC SECRETION Before and after iron therapy, the minimum $p \mathrm{H}$ of gastric secretion was 2.0 in 32 patients; $p H$ was 4 in three patients before therapy and it rose to 2 in two of them and $p \mathrm{H}$ was 7 both before and after therapy in one patient.

EFFECT OF IRON ON ACID OUTPUT IN RELATION TO SEX The mean and SD of the differences between the two tests in the same patient were $0.776 \pm 3.134$ m-equiv/hr for males and $1.206 \pm 2.745 \mathrm{~m}$-equiv/ $\mathrm{hr}$ for 15 females. The differences were not significant $(P=0 \cdot 35)$. Amongst 27 patients with iron-deficiency anaemia due to blood loss, the rise in acid output was not statistically different in males and females $(P=0 \cdot 45)$.

EFFECT OF IRON ON ACID OUTPUT IN RELATION TO AGE In 18 patients, each up to the age of 30 years and above it, the mean and SD of the differences between the two tests in the same patient were $1.42 \pm 3.104$ $\mathrm{m}$-equiv $/ \mathrm{hr}$ and $0.06 \pm 2.947 \mathrm{~m}$-equiv $/ \mathrm{hr}$ respectively (Fig. 3). The difference of increase in acid output between the two age groups was probably significant $(0.01<\mathbf{P}<0.05)$.

EFFECT OF IRON ON ACID OUTPUT IN RELATION TO INITIAL LEVELS OF ACID SECRETION Amongst patients with acid output of less than $5,5 \cdot 1-10,10 \cdot 1-15$, and more than $15.0 \mathrm{~m}$-equiv $/ \mathrm{hr}$, acid output was increased by more than $3 \mathrm{~m}$-equiv/hr in one of 10 , three of six, four of 14 , and 0 of six patients respectively (Fig 3). In patients with acid output of less than $5 \mathrm{~m}$-equiv/hr or more than $15 \mathrm{~m}$-equiv/hr, the rise in acid output was poor compared to those with values between 5 and $15 \mathrm{~m}$-equiv/hr. 


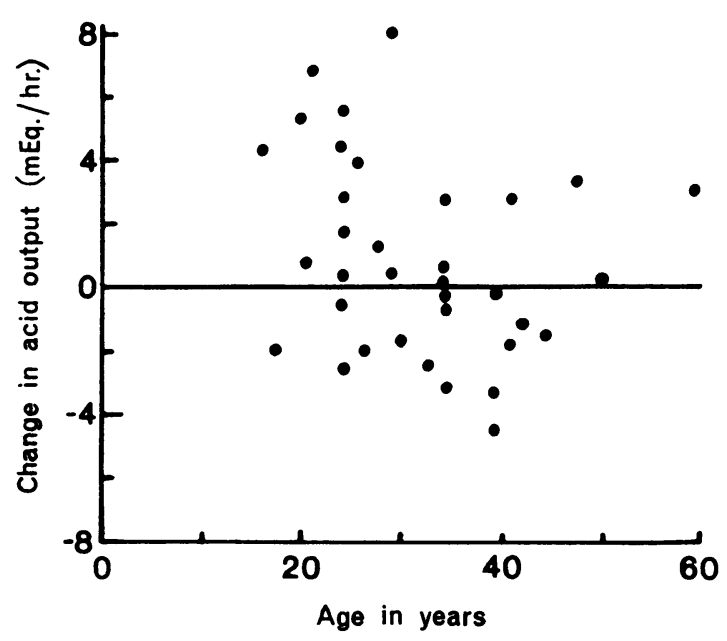

FIG. 2. Effect of intravenous iron therapy on gastric acid output in relation to age.

EFFECT OF IRON ON ACID OUTPUT IN RELATION TO HAEMOGLOBIN LEVELS In 18 patients each with $\mathrm{Hb}$ levels of up to $4 \mathrm{~g}$. and above it, the acid output did not differ significantly both before and after iron therapy $(P>0.05)$.

EFFECT OF IRON ON ACID OUTPUT IN RELATION TO THE AETIOLOGY OF IRON-DEFICIENCY ANAEMIA The mean and SD of the differences between the two tests in the same patient were $1.09 \pm 3.03 \mathrm{~m}$-equiv/hr for 27 patients with iron-deficiency anaemia secondary to blood loss and $0.53 \pm 2.8 \mathrm{~m}$-equiv/hr for nine patients with 'idiopathic' iron-deficiency anaemia. The differences were not significant $(P=0 \cdot 30)$.

ACID OUTPUT AFTER CORRECTION OF ANAEMIA In Six patients, who agreed to the procedure for the third time, the histamine infusion test was repeated after about six to eight weeks when the haemoglobin level was more than $10 \mathrm{~g} . / 100 \mathrm{ml}$. A significant rise in acid output was observed in three patients (cases $1,3,4$ ).

\section{TABLE II}

MEASUREMENT OF GASTRIC ACID OUTPUT AFTER CORRECTION OF ANAEMIA

\begin{tabular}{|c|c|c|c|c|}
\hline \multirow{2}{*}{$\begin{array}{l}\text { Case } \\
\text { No. }\end{array}$} & \multirow{2}{*}{$\begin{array}{l}\text { Sex } \\
\text { and } \\
\text { Age }\end{array}$} & \multicolumn{3}{|c|}{ Maximal Histamine Response (m-equiv/hr) } \\
\hline & & Initial & $\begin{array}{l}\text { After } \\
\text { Intravenous } \\
\text { Iron }\end{array}$ & $\begin{array}{l}\text { With } \\
\text { Normal Hb }\end{array}$ \\
\hline
\end{tabular}

\begin{tabular}{|c|c|c|c|c|}
\hline $\begin{array}{l}1 \\
2 \\
3 \\
4 \\
5 \\
6\end{array}$ & $\begin{array}{ll}\text { M } & 16 \\
\text { M } & 16 \\
\text { F } & 21 \\
\text { F } & 26 \\
\text { F } & 30 \\
\text { F } & 33\end{array}$ & $\begin{array}{r}3 \cdot 8 \\
3 \cdot 3 \\
4 \cdot 2 \\
5 \cdot 5 \\
2 \cdot 4 \\
21 \cdot 8\end{array}$ & $\begin{array}{r}7.9 \\
2.3 \\
5.0 \\
2.9 \\
4.0 \\
19.3\end{array}$ & $\begin{array}{r}28 \cdot 8 \\
0 \cdot 7 \\
9.9 \\
9 \cdot 4 \\
1 \cdot 2 \\
13.6\end{array}$ \\
\hline
\end{tabular}

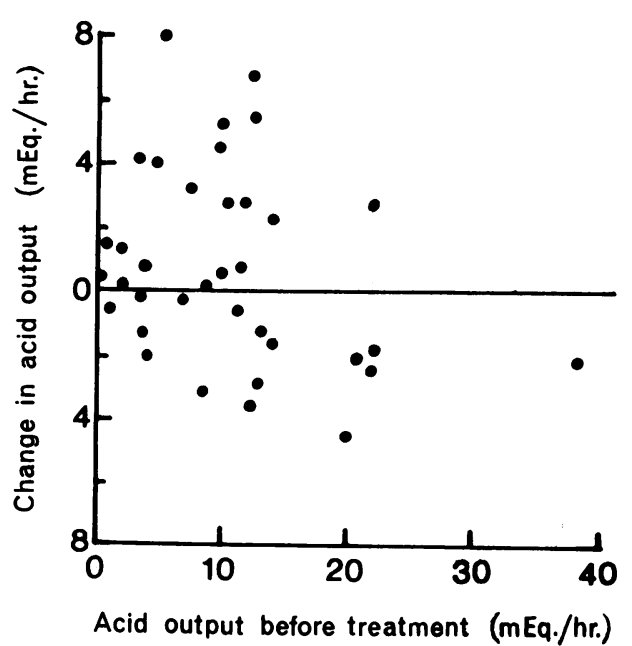

FIG. 3. Effect of intravenous iron therapy on gastric acid secretion in relation to initial levels of acid output.

GASTRIC BIOPSY The biopsy was normal in four, the stroma was heavily infiltrated with lymphocytes and plasma cells in three (glands normal), chronic superficial gastritis was noted in one, and atrophic gastritis was present in two patients.

\section{DISCUSSION}

In iron-deficiency anaemia, the reduction in acid output was associated with (1) gastric mucosal abnormalities (Davidson and Markson, 1955); (2) anaemia (Floch and Meroney, 1962); and/or (3) deficiency of an iron-containing enzyme system (Delamore and Shearman, 1965). However, in the majority of patients with iron-deficiency anaemia due to blood loss, the gastric mucosa was normal or showed mild abnormalities (Coghill, 1960; Cowan et al., 1966) and correction of anaemia neither improved the histology (Davidson and Markson, 1955; Lees and Rosenthal, 1958) nor increased the acid output (Floch and Meroney, 1962; Vaish et al., 1965). Hence, the reduction in acid output in this group of patients at least might be partly due to deficiency of an iron-containing enzyme system, as deficiencies of certain enzymes were reported in iron-deficient animals and human subjects by Beutler and Blaisdell (1960) and by Jacobs (1961).

The results of the present study showed that a significant increase in acid output, at least in the next two to three days, was not observed in the whole group. However, patients under the age of 30 years and those with acid output between 5 and 15 m-equiv/hr, showed a probably significant increase 
in acid output. This finding supports the hypothesis that deficiency of an iron-containing enzyme system probably plays some role in reduction in acid output in iron-deficiency anaemia. The failure of iron administration to increase acid output, in patients with very low acid output ( $<5 \mathrm{~m}$-equiv/hr) and in those above the age of $\mathbf{3 0}$ years, was probably due to very severe gastric mucosal atrophy in them. In patients with normal acid output, the acid secretion was probably not affected by iron deficiency. In three out of six patients, acid output increased significantly after correction of anaemia and hence anaemia seems to play an even more important role in reduction of acid output in iron-deficiency anaemia than deficiency of an iron-dependent enzyme system.

In several patients with acid output of less than $5 \mathrm{~m}$-equiv/hr, the $p \mathrm{H}$ values were low $(p \mathrm{H} 2)$, suggesting that concentration of acid was not affected in iron-deficiency anaemia. A similar observation was also made by Jacobs et al. (1966). The reduction in acid output was due to reduction in volume of gastric secretion.

Chronic atrophic gastritis was observed in only two out of 10 patients and other patients with a low acid output had normal gastric mucosa. These findings also suggested that reduction of acid output in iron-deficiency anaemia secondary to blood loss was probably not due to chronic gastritis alone but other factors such as anaemia and deficiency of an iron-dependent enzyme system also affected gastric secretion.

In patients with iron-deficiency anaemia, the acid output on the histamine infusion test was reduced compared with that observed in control subjects $(<12 \mathrm{~m}$-equiv $/ \mathrm{hr})$ in $58 \%$ of patients and achlorhydria was present in one $(2.8 \%)$ out of 36 patients studied. In contrast, in patients with idiopathic iron-deficiency anaemia studied in Britain, the acid output was found to be reduced in $80 \%$ of patients and achlorhydria was present in $13(30 \%)$ out of 44 patients studied (Jacobs et al., 1966). It is important to point out that the vast majority of Indian patients were males in whom the anaemia was secondary to blood loss while patients from Britain were females with idiopathic iron-deficiency anaemia, and hence the two groups are not strictly comparable. The differences might be explained by the observation that the incidence of parietal cell antibodies is higher in females compared with that in males in iron-deficiency anaemia (Coghill, Doniach, Roitt, Mollin, and Williams, 1965) indicating greater susceptibility of the gastric mucosa in women to develop gastritis compared with men. Alternatively, the differences of gastric acid secretion in irondeficiency anaemia patients from India and Britain might be due to different responses of gastric mucosa in these two genetically different populations.

\section{SUMMARY}

In 36 patients from Bombay with severe iron-deficiency anaemia $(\mathrm{Hb}<7 \mathrm{~g} . / 100 \mathrm{ml}$.) of varied aetiology, gastric acid output was measured with the histamine infusion test, before and after intravenous iron dextran (Imferon) therapy and before the correction of anaemia. The results showed that patients under the age of 30 years and those with an acid output between 5 and $15 \mathrm{~m}$-equiv/hr showed a probably significant rise in acid output but no significant increase in acid output was observed in patients above the age of 30 years or those with acid output of less than 5 or more than 15 m-equiv/hr. Furthermore, a significant rise in acid output was observed after correction of anaemia in some patients.

\section{REFERENCES}

Adams, J. F., Glen, A. I. M., Kennedy, E. H., Mackenzie, I. L., Morrow, J. M., Anderson, J. R., Gray, K. G., and Middleton, D. G. (1964). The histological and secretory changes in the stomach in patients with autoimmunity to gastric parietal cells. Lancet, 1, 401-403.

Badenoch, J., Evans, J. R., and Richards, W. C. D. (1957). The stomach in hypochromic anaemia. Brit. J. Haemat., 3, 175-185.

Bock, O. A. A., Richards, W. C. D., and Witts, L. J. (1963). The relationship between acid secretion after augmented histamine stimulation and the histology of the gastric mucosa. Gut, 4, 112-114.

Beutler, E., and Blaisdell, R. K. (1960). Iron enzymes in iron deficiency. V. Succinic dehydrogenase in rat liver, kidney and heart. Blood, 15, 30-35.

Coghill, N. F. (1960). The significance of gastritis. Postgrad. med. J., 36, 733-742.

—, Doniach, D., Roitt, I. M., Mollin, D. L., and Williams, A. W. (1965). Autoantibodies in simple atrophic gastritis. Gut, 6, 48-56.

Cowan, B., Joseph, S., and Satija, V. K. (1966). The gastric mucosa in anaemia in Punjabis. Ibid., 7, 234-243.

Crosby, W. H., and Kugler, H. W. (1957). Intraluminal biopsy of the small intestine: the intestinal biopsy capsule. Amer. J. dig. Dis., 2, 236-241.

Dacie, J. V., and Lewis, S. M. (1963). Practical Haematology, 3rd ed. Churchill, London.

Dagg, J. H., Goldberg, A., Anderson, J. R., Beck, J. S., and Gray, K. G. (1964). Autoimmunity in iron-deficiency anaemia. Brit. med.J., 1, 1349-1350.

Davidson, W. M. B., and Markson, J. L. (1955). The gastric mucosa in iron deficiency anaemia. Lancet, 2, 639-643.

Delamore, I. W., and Shearman, D. J. C. (1965). Chronic irondeficiency anaemia and atrophic gastritis. Ibid., 1, 889-891.

Floch, M. H., and Meroney, W. H. (1962). Human gastric electrolyte secretion in certain anemias. Amer. J. med. Sci., 244, 564-574.

Glass, G. B. J., Speer, F. D., Nieburgs, H. E., Ishimori, A., Jones, E. L., Baker, H., Schwartz, S. A., and Smith, R. (1960). Gastric atrophy, atrophic gastritis, and gastric secretory failure. Gastroenterology, 39, 429-453.

Ikkala, E., and Siurala, M. (1964). Gastric lesion in iron deficiency anaemia. Acta haemat. (Basel), 31, 313-324.

Jacobs, A. (1961). Iron-containing enzymes in the buccal epithelium. Lancet, 2, 1331-1333.

_- Lawrie, J. H., Entwistle, C. C., and Campbell, H. (1966). Gastric acid secretion in chronic iron-deficiency anaemia. Ibid., 2 190-192.

Joske, R. A., Finckh, E. S., and Wood, I. J. (1955). Gastric biopsy. A study of 1,000 consecutive successful gastric biopsies. Quart. J. Med., 24, 269-294. 
Lawrie, J. H., Smith, G. M. R., and Forrest, A. P. M. (1964). The histamine-infusion test. Lancet, 2, 270-273.

Lees, F., and Rosenthal, F. D. (1958). Gastric mucosal lesions before and after treatment in iron deficiency anaemia. Quart. J. Med., 27, 19-26.

Leonard B. J. (1954). Hypochromic anaemia in R.A.F. recruits. Lancet, 1, 899-902.

Ramsay, W. N. M. (1957). The determination of iron in blood plasma or serum. Clin. chim. Acta, 2, 214-220.
Shearman, D. J. C., Delamore, I. W., and Gardner, D. L. (1966). Gastric function and structure in iron deficiency. Lancet, 1 , 845-848.

Vaish, S. K., Sampathkumar, J., Jacob, R., and Baker, S. J. (1965). The stomach in tropical sprue. Gut, 6, 458-465.

Williams, A. W., Edwards, F., Lewis, T. H. C., and Coghill, N. F. (1957). Investigation of non-ulcer dyspepsia by gastric biopsy. Brit. med. J., 1, 372-377. 